\title{
VOICE DISORDERS IN OCCUPATIONS WITH VOCAL LOAD IN SLOVENIA GLASOVNE TEŽAVE V POKLICIH Z GLASOVNO OBREMENITVIJO V SLOVENIJI
}

\author{
Lučka BOLTEŽAR ${ }^{1}$, Maja ŠEREG BAHAR ${ }^{2, *}$ \\ 1 University Medical Centre Ljubljana, Zaloška 2, 1000 Ljubljana, Slovenia \\ 2 University Medical Centre Ljubljana, Department of Otorhinolaryngology and Head \& Neck Surgery, Zaloška 2, \\ 1000 Ljubljana, Slovenia
}

\section{ABSTRACT \\ Keywords: \\ Professional voice users, voice disorders, voice care, vocal load, questionnaires}

Aim. The aim of this paper is to compare the prevalence of voice disorders and the risk factors for them in different occupations with a vocal load in Slovenia.

Methods. A meta-analysis of six different Slovenian studies involving teachers, physicians, salespeople, catholic priests, nurses and speech-and-language therapists (SLTs) was performed. In all six studies, similar questions about the prevalence of voice disorders and the causes for them were included.

Results. The comparison of the six studies showed that more than $82 \%$ of the 2347 included subjects had voice problems at some time during their career. The teachers were the most affected by voice problems. The prevalent cause of voice problems was the vocal load in teachers and salespeople and respiratory-tract infections in all the other occupational groups. When the occupational groups were compared, it was stated that the teachers had more voice problems and showed less care for their voices than the priests. The physicians had more voice problems and showed better consideration of vocal hygiene rules than the SLTs. The majority of all the included subjects did not receive instructions about voice care during education.

Conclusions. In order to decrease the prevalence of voice disorders in vocal professionals, a screening program is recommended before the beginning of their studies. Regular courses on voice care and proper vocal technique should be obligatory for all professional voice users during their career. The inclusion of dysphonia in the list of occupational diseases should be considered in Slovenia as it is in some European countries.

\section{IZVLEČEK}

Ključne besede:

poklicni govorniki, glasovne motnje, skrb za glas, glasovne obremenitve, vprašalniki
Cilj. Primerjati prevalenco glasovnih motenj in dejavnikov tveganja za njihov nastanek pri različnih poklicih $\checkmark$ Sloveniji.

Metode. Narejena je bila meta analiza šestih različnih raziskav v Sloveniji, ki so vključevale zdravnike, učitelje, prodajalce, duhovnike, medicinske sestre in logopede. $V$ vseh študijah so bili uporabljeni podobni vprašalniki, ki so zajemali vprašanja o pojavu glasovnih motenj in razlogih zanje.

Rezultati. Primerjava raziskav je pokazala, da je $82 \%$ od 2.347 vključenih že imelo glasovne težave v svoji karieri. Največ težav z glasom so imeli učitelji. Glavni vzrok hripavosti pri učiteljih in prodajalcih je bila glasovna obremenitev, pri preostalih poklicih pa akutne respiratorne okužbe. Primerjava poklicev je pokazala, da imajo učitelji več glasovnih težav kot duhovniki, manj tudi skrbijo za svoj glas. Primerjava zdravnikov in logopedov je pokazala, da imajo zdravniki več glasovnih motenj, čeprav bolje skrbijo za svoj glas. Večina vprašanih ni dobila navodil glede skrbi in rabe glasu med svojim študijem.

Zaključki. Za zmanjšanje pojava glasovnih motenj bi bili potrebni presejalni pregledi kandidatov za poklice z glasovno obremenitvijo še pred začetkom študija. Poklicni govorniki bi se morali tudi med opravljanjem svojega poklica dodatno izobraževati o skrbi za glas in pravilni vokalni tehniki. Glasovne motnje bi morali vključiti v seznam poklicnih bolezni, tako kot je to urejeno že ponekod v Evropi. 


\section{INTRODUCTION}

In modern societies, about one-third of the labor force works in occupations for which the voice is the primary tool (1). The term "professional voice users" has been defined for those who depend on a consistent, special or appealing voice quality as a primary tool of their trade and those who if afflicted with dysphonia or aphonia would generally be discouraged in their jobs and seek alternative employment (2). Therefore, among professional voice users, not only singers and actors but also clergy, teachers, receptionists, sales personnel, physicians and anyone else whose ability to earn a living is impacted negatively by a loss of vocal quality and endurance are included (3). Koufman et al. defined four levels of vocal users: the elite vocal performer (singers, actors), professional voice user (clergy, lecturers, telephone operators), the non-vocal professional (teachers, doctors, lawyers, businessmen, receptionists, etc.) and the non-vocal nonprofessional (laborers, clerks) (4). Vilkman classifies voice professionals according to the demands put on their voice and the vocal load. Actors and singers need a high voice quality and their vocal load is high. Teachers, telephone operators, clergy, etc. need a moderate voice quality, but they have a high vocal load. Physicians, nurses, lawyers, etc. need moderate voice quality and have a moderate vocal load (1).

Verdolini and Ramig tried to estimate the prevalence of voice problems in different occupations in the workforce. In several countries, teaching was the most common occupation among the visitors to voice clinics. Other occupations likely to search for otorhinolaryngological help for voice problems included singer, counselor/social worker, lawyer and clergy (5).

In the USA, workers in sales and sales-related occupations (13\%) and teachers (4.2\%) represent the largest percentage of professional voice users. Clergy, psychologists, counselors and speech-and-language pathologists constitute only $0.8 \%$ of the workforce, but they make up a much larger section of the patients with voice problems. In any case, teachers are still the most frequent visitors to voice clinics (2).

Teachers are one of the most affected occupations with respect to voice disorders (6-8). In the USA, a greater prevalence for reporting a current voice problem and a prevalence for voice disorders during their lifetime were noted in the teacher population more than in other occupations. The identified risk factors for voice disorders were being a woman, being between 40 and 59 years of age, having 16 or more years of education and having a family history of voice disorders (7). However, being a university teacher was associated with good vocal quality and no handicapping effect from possible voice disorders (9). Voice disorders were more prevalent in teachers in nurseries (36.4\%) than for those in elementary school $(25 \%)$ and in high school (20.8\%). The width and depth of classrooms, a larger number of students, longer classroom hours and the level of noise were related to the frequency of voice disorders (10). Lehto also identified the risk factors for voice disorders in other voice professions such as: background noise, poor air quality (dryness, dust), poor posture and vocal loading (11).
Over $20 \%$ of teachers had missed some days at work due to a voice problem $(12,13)$. When compared to the general population, teachers had missed more working days in the preceding year because of voice problems and were more likely to consider changing their occupation because of problems with their voice (14). Voice disorders in teachers were also associated with major episodes of depression, general anxiety disorder and phobias (15).

There are rare studies comparing different occupations with a vocal load. A comparison between day-care teachers and nurses was made in Finland. The teachers had more voice problems $(12 \%$ vs. $7 \%)$, which was connected with higher background-noise levels and poor acoustics in the rooms (8).

Dysphonia related to vocal load during work is an occupational disease in France and Russia but not in Germany, the UK, Italy or Slovenia (16). In Croatia, the vocal nodules that appear as a result of occupational voice use are considered an occupational disease (17).

Voice disorders are not considered as an occupational disease in Slovenia. Therefore, the aim of this paper is to present the extent of the problem of dysphonia as an occupation-related disease in professional voice users. A meta-analysis of several studies was performed in order to compare the prevalence of voice disorders and the risk factors for them in different occupations with a vocal load in Slovenia.

\section{METHODS}

A meta-analysis was made of six different Slovenian studies among occupations with a vocal load (18-23). Some Slovenian studies were identified through the union bibliographic/catalogue database COBIB.SI search using the keywords "professional voice disorders". The other studies were found in the COBISS bibliography of the authors of these papers. In all six studies, including teachers, physicians, salespeople, catholic priests, speech-and-language therapists (SLTs) and nurses, very similar questionnaires were used. The core of every questionnaire included the same questions about age, gender, the prevalence of voice disorders in the current year, in the entire career and during education, the causes of voice disorders (vocal load and/or respiratory-tract infection or other), vocal habits (speaking loudly, shouting frequently, fast speaking rate, vocal rest when encountering voice problems), frequent throat clearing, sufficient hydration and smoking. In some studies, the questions about daily vocal load, length of career, instructions about voice care, typical symptoms of gastroesophageal reflux (heartburn, acid regurgitation) and allergies were also part of the questionnaire.

The results of the questionnaires were compared between the occupational groups with similar vocal loads according to Vilkman, e.g. teachers versus priests and physicians versus SLTs. The t-test and x2-test or Fischer's Exact test of the program package SPSS 19.0 (SPSS Corporation, USA) were used for the statistical analysis. 


\section{RESULTS}

The six studies (18-23) involved a total of 2347 subjects (599 men, 1748 women).

The majority of all the included subjects with occupations involving a vocal load had experienced voice problems during their professional career, $16.7 \%$ of them admitted to frequent voice problems. The teachers, the nurses and the physicians declared the highest prevalence of voice problems in their career. Their voice problems were caused by vocal load in the majority of teachers and salespeople and by respiratory-tract infections in more than $40 \%$ of nurses and physicians. In the case of hoarseness, less than one half of the included subjects have voice rest. In three studies, $13.6 \%$ of the participants missed work because of voice problems. More than one half of the included subjects have improper voice habits: in particular, they speak loudly. The detailed results of the questionnaires are listed in Table 1.
In Slovenian teachers, the following risk factors for voice disorders were identified: female gender, age over 40 years and allergies.

In catholic priests, the risk factors for frequent voice disorders were vocal load during spare time, not getting instructions about voice care, voice disorders during education and frequent throat clearing.

Among the Slovenian physicians with frequent voice disorders, most were those who did not respect voice rest when having voice problems, those with frequent throat clearing and those with allergies.

In SLTs, the following risk factors for voice disorders were identified: improper voice technique and frequent cough.

Smoking was a risk factor for voice disorders in nurses.

When the groups of priests and teachers were compared, some significant differences were found. Firstly, priests are only men. Secondly, the teachers had a significantly

Table 1. Results of the questionnaires about voice problems in six different occupations with a vocal load in Slovenia (18-23).

\begin{tabular}{|c|c|c|c|c|c|c|}
\hline Parameter & $\begin{array}{l}\text { Priests } \\
N=340\end{array}$ & $\begin{array}{l}\text { Teachers } \\
\mathrm{N}=1509\end{array}$ & $\begin{array}{c}\text { Physicians } \\
\mathrm{N}=145\end{array}$ & $\begin{array}{l}\text { Speech and } \\
\text { language } \\
\text { therapists } \\
\mathrm{N}=111\end{array}$ & $\begin{array}{l}\text { Salespersons } \\
\qquad N=136\end{array}$ & $\begin{array}{l}\text { Nurses } \\
N=106\end{array}$ \\
\hline Age (mean/stand dev. - years) & $52.1 / 13.2$ & $40.4^{*}$ & $44.7 / 8.2$ & $43 / 6.7$ & 41.9 & $42.6 / 0.3$ \\
\hline Gender (M/F) & $340 / 0$ & $196 / 1313$ & $33 / 112$ & $0 / 111$ & $21 / 115$ & $9 / 97$ \\
\hline Career length (mean - years) & 25.7 & $19.8^{*}$ & 18.2 & 20.4 & 19.6 & 22.1 \\
\hline Vocal load/day (mean - hours) & 3.7 & $4.8^{* *}$ & 6.8 & 6 & 8.4 & 8.7 \\
\hline Vocal load during spare time & $100(29.4 \%)$ & $389(25.8 \%)$ & $29(20 \%)$ & $18(16.2 \%)$ & $27(19.9 \%)$ & $14(13.2 \%)$ \\
\hline Instructions about voice care & $164(48.2 \%)$ & & & & $21(15.4 \%)$ & $12(11.3 \%)$ \\
\hline Voice disorders in the current year & $230(67.7 \%)$ & $989(65.5 \%)$ & 77 (53.1 \%) & $42(37.8 \%)$ & $85(62.5 \%)$ & $53(50 \%)$ \\
\hline Voice disorders in career & 237 (69.7\%) & $1338(88.7 \%)$ & $120(82.8 \%)$ & $48(43.3 \%)$ & $95(69.9 \%)$ & $94(88.7 \%)$ \\
\hline Frequent voice disorders in career & $54(15.9 \%)$ & $273(18.1 \%)$ & $11(7.6 \%)$ & $5(4.5 \%)$ & & $27(25.5 \%)$ \\
\hline Voice disorders during education & $53(15.6 \%)$ & $109(7.2 \%)$ & $29(20 \%)$ & $12(10.8 \%)$ & $14(10.3 \%)$ & $10(9.4 \%)$ \\
\hline $\begin{array}{l}\text { A cause for voice disorders: } \\
\text { - vocal load } \\
\text { - respiratory tract infection } \\
\text { - vocal load + resp. tract infection } \\
\text { - other }\end{array}$ & $\begin{array}{c}99(29.1 \%) \\
119(35 \%) \\
47(13.8 \%) \\
22(6.5 \%)\end{array}$ & $\begin{array}{c}695(46.1 \%) \\
428(28.4 \%) \\
200(13.2 \%)\end{array}$ & $\begin{array}{l}17(11.7 \%) \\
85(58.6 \%) \\
23(15.8 \%) \\
20(13.8 \%)\end{array}$ & $\begin{array}{l}15(13.6 \%) \\
40(36.0 \%) \\
40(36.0 \%)\end{array}$ & $\begin{array}{l}93(68 \%) \\
43(32 \%)\end{array}$ & $\begin{array}{l}16(15.1 \%) \\
47(44.3 \%) \\
11(10.4 \%)\end{array}$ \\
\hline Missing work because of voice problems & $41(12.1 \%)$ & & & & $23(17 \%)$ & $15(14.1 \%)$ \\
\hline Voice rest during voice problems & $72(21.2 \%)$ & 477 (31.6 \%) & $69(47.6 \%)$ & $58(52 \%)$ & $44(32.4 \%)$ & $32(30.2 \%)$ \\
\hline Speaking loudly & $258(75.9 \%)$ & 741 (49.1 \%) & $80(55.2 \%)$ & $51(46 \%)$ & $79(58.1 \%)$ & $55(51.9 \%)$ \\
\hline Shouting frequently & $33(9.7 \%)$ & $144(9.5 \%)$ & $13(8.9 \%)$ & $9(8 \%)$ & $19(13.9 \%)$ & $17(16 \%)$ \\
\hline Fast speaking rate & $115(33.8 \%)$ & $572(37.9 \%)$ & $66(45.5 \%)$ & $37(33.3 \%)$ & $46(33.8 \%)$ & $42(39.6 \%)$ \\
\hline Frequent throat clearing & $189(55.6 \%)$ & $568(37.6 \%)$ & $42(28.9 \%)$ & $25(22.5 \%)$ & $64(47.1 \%)$ & $39(36.8 \%)$ \\
\hline Heartburn and acid regurgitation & $112(32.9 \%)$ & 405 (26.8 \%) & $62(42.7 \%)$ & & $45(33.1 \%)$ & $30(28.3 \%)$ \\
\hline Allergy, asthma & $52(15.3 \%)$ & $212(14 \%)$ & $27(18.6 \%)$ & & $18(13.2 \%)$ & $16(15.1 \%)$ \\
\hline Smoking & $26(7.6 \%)$ & 275 (18.1\%) & $10(6.9 \%)$ & $27(24.3 \%)$ & $49(36 \%)$ & $19(17.9 \%)$ \\
\hline Sufficient hydration & 278 (81.8 \%) & 747 (49.5 \%) & $114(78.6 \%)$ & $73(65.7 \%)$ & 104 (76.5 \%) & $99(93.4 \%)$ \\
\hline
\end{tabular}

*calculated from the Figure 2 (18)

${ }^{* *}$ calculated from the minimum weekly obligation for teachers in schools ( $72 \%$ of included subjects; minimum obligation 22 hours/week) and nurseries ( $28 \%$ of included subjects; minimum obligation 30 hours/week) in Slovenia (18) 
Table 2. Comparison of the results from questionnaires about voice problems between catholic priests and teachers in Slovenia $(18,23)$.

\begin{tabular}{|c|c|c|c|}
\hline Parameter & $\begin{array}{l}\text { Priests } \\
\mathrm{N}=340\end{array}$ & $\begin{array}{l}\text { Teachers } \\
\mathrm{N}=1509\end{array}$ & $\mathrm{p}$ \\
\hline Age (mean - years) & 52.1 & $40.4^{*}$ & \\
\hline Gender (M/F) & $340 / 0$ & $196 / 1313$ & 0.000 \\
\hline $\begin{array}{l}\text { Voice disorders in the current } \\
\text { year }\end{array}$ & 230 & 989 & 0.486 \\
\hline Voice disorders in career & 237 & 1338 & 0.000 \\
\hline $\begin{array}{l}\text { Frequent voice disorders in } \\
\text { career }\end{array}$ & 54 & 273 & 0.387 \\
\hline Voice disorders during education & 53 & 109 & 0.000 \\
\hline $\begin{array}{l}\text { A cause for voice disorders: } \\
\text { - vocal load }\end{array}$ & 99 & 695 & 0.000 \\
\hline $\begin{array}{l}\text { A cause for voice disorders: } \\
\text { - respiratory-tract infection }\end{array}$ & 119 & 428 & 0.018 \\
\hline $\begin{array}{l}\text { A cause for voice disorders } \\
\text { - respiratory-tract infection } \\
\text { + vocal load }\end{array}$ & 47 & 200 & 0.791 \\
\hline Voice rest during voice problems & 72 & 477 & 0.000 \\
\hline Speaking loudly & 258 & 741 & 0.000 \\
\hline Shouting frequently & 33 & 144 & 0.919 \\
\hline Fast speaking rate & 115 & 572 & 0.172 \\
\hline Frequent throat clearing & 189 & 568 & 0.000 \\
\hline $\begin{array}{l}\text { Typical symptoms of } \\
\text { gastroesophageal reflux }\end{array}$ & 112 & 405 & 0.027 \\
\hline Vocal load during spare time & 100 & 389 & 0.174 \\
\hline Smoking & 26 & 275 & 0.000 \\
\hline Sufficient hydration & 278 & 747 & 0.000 \\
\hline Allergy, asthma & 52 & 212 & 0.549 \\
\hline
\end{tabular}

*calculated from the Figure 2 (18)

higher prevalence of voice disorders during their careers and during education, with vocal load being the most frequent cause of dysphonia. Thirdly, there were more smokers among the teachers than among the priests. Finally, the priests are better at taking care to have sufficient hydration, but most of them speak loudly and do not take voice rest when they are having voice problems. They also have more problems with gastroesophageal reflux than the teachers. The comparison is presented in Table 2.

When the physicians and the SLTs were compared, the groups were significantly different with regards to gender, the prevalence of voice disorders during their careers, the causes of voice disorders and smoking. The results are given in Table 3.

\section{DISCUSSION}

The aim of this paper is to present the extent of the problem of dysphonia as an occupation-related disease in
Table 3. Comparison of the results from questionnaires about voice problems between physicians and speech-and-language therapists in Slovenia $(19,21)$.

\begin{tabular}{|c|c|c|c|}
\hline Parameter & $\begin{array}{l}\text { Physicians } \\
\mathrm{N}=145\end{array}$ & $\begin{array}{l}\text { Speech and } \\
\text { language } \\
\text { therapists } \\
\mathrm{N}=111\end{array}$ & $\mathrm{p}$ \\
\hline Age (mean - years) & $44.7 / 8.2$ & $43 / 6.7$ & 0.077 \\
\hline Gender (M/F) & $33 / 112$ & $0 / 111$ & 0.000 \\
\hline Vocal load (hours/day) & 6.8 & 6 & \\
\hline $\begin{array}{l}\text { Voice disorders in the current } \\
\text { year }\end{array}$ & 77 & 42 & 0.017 \\
\hline Voice disorders in career & 120 & 48 & 0.000 \\
\hline $\begin{array}{l}\text { Frequent voice disorders in } \\
\text { career }\end{array}$ & 11 & 5 & 0.436 \\
\hline $\begin{array}{l}\text { Voice disorders during } \\
\text { education }\end{array}$ & 29 & 12 & 0.058 \\
\hline $\begin{array}{l}\text { A cause for voice disorders: } \\
\text { - vocal load }\end{array}$ & 17 & 15 & 0.706 \\
\hline $\begin{array}{l}\text { A cause for voice disorders: } \\
\text { - respiratory tract infection }\end{array}$ & 85 & 40 & 0.000 \\
\hline $\begin{array}{l}\text { A cause for voice disorders: } \\
\text { - vocal load and respiratory- } \\
\text { tract infection }\end{array}$ & 23 & 40 & 0.000 \\
\hline $\begin{array}{l}\text { Voice rest during voice } \\
\text { problems }\end{array}$ & 69 & 58 & 0.528 \\
\hline Speaking loudly & 80 & 51 & 0.131 \\
\hline Shouting frequently & 13 & 9 & 1.000 \\
\hline Fast speaking rate & 66 & 37 & 0.054 \\
\hline Frequent throat clearing & 42 & 25 & 0.255 \\
\hline Vocal load during spare time & 29 & 18 & 0.516 \\
\hline Smoking & 10 & 27 & 0.000 \\
\hline Sufficient hydration & 114 & 73 & 0.024 \\
\hline
\end{tabular}

professional voice users in Slovenia. The results of metaanalysis of six Slovenian studies of voice disorders among different occupations with a vocal load (18-23) showed that more than $82 \%$ of all the included subjects had voice problems at some time during their career, with $16.7 \%$ having frequent voice problems. However, only with teachers and salespeople was vocal load the prevalent cause of the voice problems. All the other occupational groups had voice problems, mostly because of respiratory-tract infections. Less than one-third (32\%) of the participants can afford a voice rest when suffering from voice problems, and $13.6 \%$ miss work because of dysphonia. More than one half of the participants with a vocal load at work have improper speaking habits (e.g., speaking loudly, 53.9\%). A considerable number of the participants have some diseases or habits influencing voice quality (gastroesophageal reflux $29 \%$, asthma and allergies $14.5 \%$, frequent throat clearing $39.5 \%$ and smoking $17.3 \%$ ). The vast majority of the included subjects did not get any information about voice care. 
The study demonstrated that important information about prevalence of voice problems cannot be obtained only from the papers included in the PubMed database. One out of six included studies was published in the proceeding book of a national otorhinolaryngological congress (20). The other two studies were graduate theses at the University of Ljubljana, Faculty of Education, Department for SLTs $(21,22)$. They were found through the COBIB.SI database and in the COBISS bibliography of one of the authors of the papers published in the $\mathrm{SCl}$ journals. Therefore, for a more complete impression about the problem of voice disorders in the occupations with vocal load in Slovenia, the papers from so-called "grey literature" also had to be included.

In order to demonstrate the importance of knowledge of voice care, two occupations with a similar vocal load and different study programs regarding information about voice care were compared. We compared the teachers and the priests because at work they both speak to groups of people, and the physicians and the SLTs because they have mostly one-to-one communication at work. In Slovenia, some information about vocal technique, the causes of voice disorders and voice care is presented to future SLTs, priests and physicians during their regular educational program. The priests obtain the knowledge during their regular educational program of choral singing. The physicians get information about the causes and treatment of voice disorders during their course on ear, nose and throat diseases but do not receive any vocal training. In the past 15 years, the study program for SLTs has included a one-semester course on the pathology of voice. In the last 5 years, a course on voice therapy has been added to the curriculum.

In Slovenia, future teachers do not get any information about voice care during their education. The prevalence of voice disorders among teachers in Slovenia was reported to be about the highest among all included occupations $-88.7 \%$. More than $18 \%$ of teachers had frequent voice disorders (18). A survey of Slovenian catholic priests showed that $69.7 \%$ of the included priests reported voice problems during their careers, and an additional $15.9 \%$ reported frequent problems. Not having lessons about proper vocal technique was one of the risk factors for frequent voice disorders in priests (23).

Since about one-half of the priests reported having had lessons on vocal technique, we expected better vocal habits and voice care in the priests than in the teachers. Compared to the priests, the teachers more often reported smoking $(18.1 \%$ vs. $7.6 \%)$ and not drinking enough water through the day ( $81.8 \%$ vs. $49.5 \%)$. The good hydration and non-smoking lifestyle of priests can be attributed to an awareness of a healthy life style, voice care or the nature of their work $(18,23)$.

Since about one-half of teachers reported speaking loudly quite often, their most common cause of voice problems was vocal load and overuse (46.1\%). Even though the priests claimed to speak loudly more often than the teachers (75.9\% vs. $49.1 \%)$, their most common cause of vocal problems was respiratory-tract infection (35\%). According to the results of daily vocal load, the teachers' vocal load was greater than the priests' $(18,23)$. We suppose that the time period of high vocal load at work was the most important ground for the different causes for voice problems in both groups.

Surprisingly, only $21.2 \%$ of priests and $31.6 \%$ of teachers vocally rest when they have voice problems $(p=0.000)(18$, $23)$. Only $12.1 \%$ of priests miss their work because of dysphonia (23). The reason for the significantly smaller portion of priests who have voice rest in the case of dysphonia could be the lack of priests in Slovenia. Therefore, they cannot afford to miss their work.

We expected fewer voice problems in the physicians and the SLTs in comparison with the teachers and the priests since their communication is usually with an individual and not with a large group. Since the SLTs included in the study were only women, we anticipated detecting more voice problems among them than among the physicians $(22.8 \%$ of men) $(19,21)$. The comparison of the two groups showed that the problems are more common in the physicians $(p=0.000)$. Fewer than one half of the SLTs had voice problems at some point during their working life (21), which represented the lowest prevalence of voice disorders in all the included studies (18-23). Education about voice care is probably the reason for the lowest prevalence of voice disorders in the SLTs.

The SLTs reported the highest proportion of vocal rest during voice problems (52\%) among all the studied occupations with a vocal load. On the other hand, they also reported speaking loudly quite often (46\%) (21). So even though the SLTs were the group that had the best knowledge about voice care, they still do not use it in their profession. We believe that they could benefit from more education regarding the diseases affecting voice quality and practical aspects of voice use in everyday situations.

The main reason for vocal problems in physicians is respiratory-tract infection (58.6\%) (19), which is understandable due to the nature of their work. Physicians' offices are always full of sick people, while the visitors to e.g. the SLTs are usually healthy subjects without any infections.

Salespeople and nurses are not really comparable groups with regard to their professional voice use. Both groups usually talk to an individual, but sometimes in unfavorable acoustic conditions. We suppose that the quantity of talking is much greater for the nurses. They often have to communicate with old patients who have hearing impairments. The nurses are also exposed to infections; therefore, their voice problems occurred mostly due to respiratory-tract infections (44.3\%) (22). In Slovenia, the education of salespeople and nurses does not include any instructions on vocal hygiene, so they depend on themselves to obtain the information they need. In spite of that, the salespeople reported obtaining information on voice care in $15.4 \%$ of cases and the nurses in $11.3 \%(20,22)$.

Unfortunately, the questionnaires used in all included studies did not contain questions on background noise, acoustic properties or unfavorable microclimate at the working place. The information on such external causes for voice 
disorders would even better elucidate the reasons for voice problems in different occupations with vocal load.

A survey among students in teacher-education programs in Finland showed that $20 \%$ of the students had two or more vocal symptoms during their training and as many as $19 \%$ had an organic voice disorder. The authors proposed a clinical evaluation of the students with voice symptoms and vocal training in the teacher-education programs (24). Namely, in other studies the teachers with voice problems during their training reported more voice problems later during their careers $(13,25)$.

In the Slovenian surveys, $7.2-20 \%$ of the included subjects had voice problems during education (18-23). Having voice problems during training has been shown to be one of the risk factors for later voice problems during a professional career for teachers, priests and SLTs $(18,23,26)$. Besides that, in the study of Radšel et al., it was shown that $25 \%$ of future teachers had serious voice and speech disorders, which could represent an obstacle in their future profession (27). Therefore, in order to prevent occupational dysphonia, it would be necessary to examine every candidate for the occupation with a considerable vocal load before the beginning of the study program and to allow only those with healthy vocal apparatuses to enter it. In Slovenia, such a preventive examination before the start of the educational program only applies to students of acting and solo singing and no one else. The candidates for SLTs have an interview before the beginning of the study with two experienced SLTs in order to exclude those with speech pathology, but they do not have an ENT examination. There are no ENT examinations or screening programs for future teachers, physicians, priests, nurses and salespeople. The proper selection of the candidates for the educational program could be another reason for the lowest prevalence of voice disorders in the SLTs.

Dysphonia related to vocal load during work is an occupational disease in France and Russia (16). In Croatia, the vocal nodules that appear as a result of occupational voice use are considered an occupational disease (17). In the European Union recommendations, dysphonia is on a list of diseases related to occupation (28). In Slovenia, no laryngeal diseases are on the list of occupational diseases (29).

In the development of an occupational disease, besides known etiological factors, the individual characteristics of the worker and coincidence of other general diseases are important (30). In order to recognize dysphonia as an occupational disease, the worker must have a healthy vocal tract and a proper vocal technique before starting to work in their occupation. The voice problems should always appear at work and should deteriorate with the prolonged time of vocal load at work. They should decrease after vacations or during weekends and deteriorate after coming back to work $(30,31)$. Therefore, in order to acknowledge dysphonia as an occupational disease, an ENT and SLT examination before starting work in an occupation with vocal load is essential.

\section{CONCLUSIONS}

In Slovenia, voice problems are common in occupations with an everyday vocal load. The most common causes for dysphonia are excessive vocal load, misuse of the voice and respiratory-tract infections. Our comparison study has shown that a great majority of professional voice users do not get enough knowledge about vocal hygiene during their educational programs. Up to $20 \%$ of participants had voice problems already during their educational programs, indicating unsuitable voice technique or vocal tract endurance. Therefore, further research on risk factors for voice disorders among students for occupations with vocal load is necessary.

In order to decrease the prevalence of voice disorders in professional voice users, at least a simple and quick screening tool to identify those with the highest risk of voice problems in an occupation with vocal load should be applied before beginning their education. Obligatory regular courses on voice hygiene, diseases affecting voice quality and proper vocal technique should be organized for professional voice users with the intention to increase the efficiency of their own voice care. The criteria for the inclusion of dysphonia in the list of occupational diseases should be established considering the European Union recommendations.

In the case of acute voice problems, the vocal hygiene instructions about short voice rest should be taken into consideration by the affected professional voice user. In the case of frequent or long-lasting voice problems, the patient should be sent to an otorhinolaryngologist or - even better - to a phoniatrician and a SLT-voice specialist for further treatment. Nevertheless, for successful voice rehabilitation, the patient's own activity in acquiring better vocal technique and vocal habits is indispensable.

\section{CONFLICT OF INTEREST}

The authors declare that no conflict of interest exist.

\section{FUNDING}

None.

\section{ETHICAL APPROVAL}

Not required.

\section{REFERENCES}

1. Vilkman E. Voice problems at work: a challenge for occupational safety and health arrangement. Folia Phoniatr Logop 2000; 52: 120-5.

2. Titze IR, Lemke JH, Montequin D. Populations in the U.S. workforce who rely on voice as a primary tool of trade: a preliminary report. J Voice 1997; 11: 254-9.

3. Sataloff RT. Professional voice users: the evaluation of voice disorders. Occup Med 2001; 16: 633-47. 
4. Koufman JA, Isaacson $G$. The spectrum of vocal dysfunction. Otolaryngol Clin North Am 1991; 24: 985-8.

5. Verdolini K, Ramig LO. Rewiev: occupational risks for voice problems. Logoped Phoniatr Vocol 2001; 26: 37-46.

6. Angelillo M, Di Maio G, Costa G, Angelillo N, Barillari U. Prevalence of occupational voice disorders in teachers. J Prev Med Hyg 2009; 50: 2632.

7. Roy N, Merrill RM, Thibeault S, Parsa RA, Gray SD, Smith EM. Prevalence of voice disorders in teachers and the general population. J Speech Lang Hear Res 2004; 47: 281-93.

8. Sala E, Airo E, Olkinuora P, Simberg S, Strom U, Laine A Pentti J, Suonpaa J. Vocal loading among day care center teachers. Logoped Phoniatr Vocol 2002; 27: 21-8.

9. D'haeseleer E, Claeys S, Wuyts F, Van Lierde KM. Vocal quality in university teachers: a pilot study. B-ENT 2009; 5: 101-9.

10. Preciado JA, Garcia Tapia R, Infante JC. Prevalence of voice disorders among educational professionals: factors contributing to their appearance of their persistence. Acta Otorrinolaringol Esp 1998; 49: 137-42.

11. Lehto L, Alku P, Backstrom T, Vilkman E. Voice symptoms of call-centre customer service advisers experienced during a work-day and effects of a short vocal training course. Logoped Phoniatr Vocol 2005; 30: 14-27.

12. Smith E, Gray SD, Dove H, Kirchner L, Heras H. Frequency and effects of teachers' voice problems. J Voice 1997; 11: 81-7.

13. de Jong FICRS, Kooijman PGC, Thomas G, Huinck WJ, Graamans K, Schutte HK. Epidemiology of voice problems in Dutch teachers. Folia Phoniatr Logop 2006; 58: 186-98.

14. Roy N, Merrill RM, Thibeault S, Gray SD, Smith EM. Voice disorders in teachers and the general population: effects on work performance, attendance, and future career choices. J Speech Lang Hear Res 2004; 47: 542-51.

15. Nerriere E, Vercambre MN, Gilbert F, Kovess-Masfety V. Voice disorders and mental health in teachers: a cross-sectional nationwide study. BMC Public Health 2009; 9: 370.

16. Hazlett DE, Duffy OM, Moorhead SA. Occupational voice demands and their impact on the call-centre industry. BMC Public Health 2009; 9: 108.
17. Registar profesionalnih bolesti 2012. Hrvatski zavod za zaštitu zdravlja i sigurnost na radu. Available Jan 27, 2014 from: http://hzzzsr. $\mathrm{hr} /$ ?what=content\&ID=70\&cat=68

18. Soklič T, Hočevar Boltežar I. Glasovne motnje med pedagoškimi delavci v Sloveniji: prevalenca in nekateri dejavniki tveganja. Zdrav Vestn 2004; 73: 493-7.

19. Šereg Bahar M, Soklič Košak T, Hočevar Boltežar I. Voice problems among Slovenian physicians compared to the teachers: prevalence and risk factors. Zdrav Vestn 2012; 81: 626-33.

20. Kravos A. Voice disorders in sellers. Med Razgl 2008; 47: 383-86.

21. Škofič A. Glasovne motnje pri logopedih: diplomska naloga. Ljubljana: Pedagoška fakulteta, 2004.

22. Žirovec P. Glasovne motnje pri medicinskih sestrah: diplomska naloga. Ljubljana: Pedagoška fakulteta, 2014.

23. Hočevar Boltežar I. Prevalence and risk factors for voice problems in priests. Wien Klin Wochenschr 2009; 121: 276-81.

24. Simberg S, Laine A, Sala E, Ronnemaa AM. Prevalence of voice disorders among future teachers. J Voice 2000; 14: 231-5.

25. Kooijman PGC, de Jong FICRS, Thomas G, Huinck W, Donders R, Graamans K, Schutte HK. Risk factors for voice problems in teachers. Folia Phoniatr Logop 2006; 58: 159-74.

26. Trpkov K. Voice disorders in speech and language pathologists. Med Razgl 2008; 47: 387-9.

27. Radšel Z, Jarc A, Hočevar Boltežar I. Voice and speech assessment in future teachers. In: Proceedings of XIII th Congres of Otorhinolaryngolo-

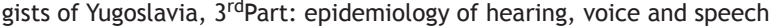
pathology, Priština, 1988: 102-7.

28. Commission Recommendation of 19 September 2003 concerning the European schedule of occupational diseases (document No. C(2003) 3297) Official Journal L 238; 25/09/2003: 28-34.

29. Pravilnik o seznamu poklicnih bolezni. Uradni list RS 2003; 85.

30. Bilban M. Medicina dela. Ljubljana: Zavod za varstvo pri delu, 1999.

31. Gluvajić D, Bilban M, Hočevar Boltežar I. Ali je glasovna motnja lahko tudi poklicna bolezen? Zdrav Vestn 2012; 81: 796-805. 